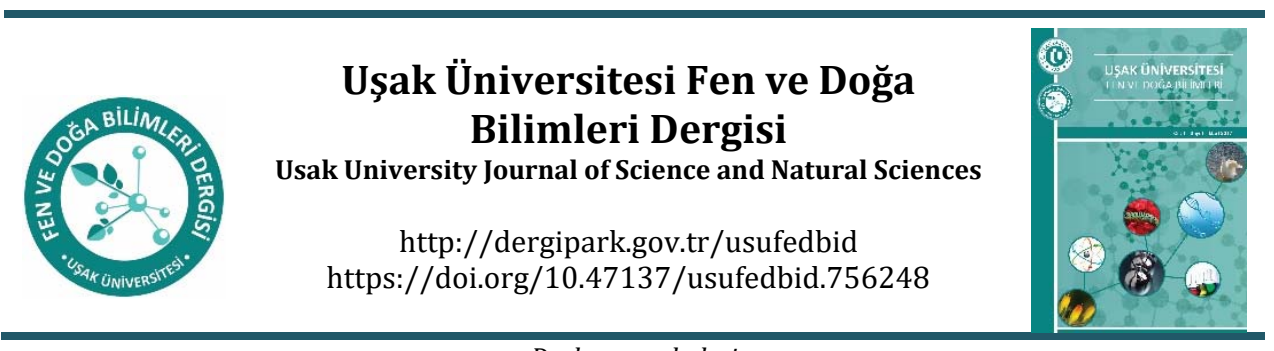

Derleme makalesi

\title{
Ülkemizde Yem Bitkileri Tarımının Durumu, Tohumluk Üretimi ve Dış Ticareti
}

\author{
Eser Ülker ${ }^{1}$, Osman Yüksel2 ${ }^{2}$, Samet Ergül² \\ 1 Uşak İl Tarım ve Orman Müdürlüğü, Uşak \\ 2 Uşak Üniversitesi, Ziraat ve Doğa Bilimleri Fakültesi, Tarla Bitkileri Bölümü, Uşak
}

Geliş: 22 Haziran 2020

Kabul: 06 Kasım 2020 / Received: 22 June 2020

Accepted: 06 November 2020

\begin{abstract}
In order to ensure sustainable growth in animal husbandry, quality roughage and concentrated feed production problems, which constitute the biggest item of production costs, must be resolved. At this point, the breeding and production of high-yielding forage crops species and varieties that can enter cultivation seizures under different ecological conditions is great importance. The trade volume of forage crops seed sector in the world is increasing day by day. On the other hand, important foreign trade deficits are given in forage crops in our country. By solving the problems of our seed sector, supporting them and increasing the investments in this field, our production of forage crops, our foreign trade, our livestock and related food needs will be secured.
\end{abstract}

Keywords: Forage crops, farming, seed production, foreign trade.

\section{Özet}

Hayvancllıta sürdürülebilir bir büyümenin temin edilebilmesi için üretim maliyetlerinin en büyük kalemini oluşturan kaliteli kaba ve kesif yem üretim sorunlarının çözülmesi gerekmektedir. Bu noktada farklı ekolojik koşullarda ekim nöbetlerine girebilen, yüksek verimli yem bitkisi tür ve çeșitlere ait tohumlukların geliștirilmesi ve üretilmesi büyük önem arz etmektedir. Dünyada yem bitkileri tohumculuk sektörünün ticaret hacmi her geçen gün artmaktadır. Buna karşın ülkemizde yem bitkileri tohumculuğunda önemli dış ticaret açıkları verilmektedir. Tohumculuk sektörümüzün sorunlarının çözülmesi, desteklenmesi ve bu alandaki yatırımların artırılmasıyla başta dış ticaretimiz olmak üzere yem bitkileri üretimimiz, hayvancılığımız ve buna bağlı gıda gereksinimimiz güvence altına alınmış olacaktır.

Anahtar Kelimeler: Yem bitkileri, üretimi, tohumculuğu, dıș ticareti.

*Corresponding author:

E-mail: osman.yuksel@usak.edu.tr

ORCID ID: 0000-0002-5972-4885

(C)2020 Usak University all rights reserved. 


\section{Giriş}

Türkiye, \%1.2 nüfus artıș hızı ile dünya ortalamasının üzerinde büyüme gösteren bir ülkedir. Hızlı nüfus artışı ülkemizin yeterli ve dengeli beslenme sorunu ile karşı karşıya kalmasına neden olmaktadır. Yeterli ve dengeli beslenmede günlük protein gereksiniminin karşılanmasında hayvansal proteinler özel bir önem taşımakta ve günlük 70 gram olan protein gereksiniminin en az 33 gramının hayvansal kökenli olması gerekmesine rağmen, bu değer ülkemizde 13-17 gram dolaylarındadır [1]. Kişi başına hayvansal protein tüketimimizin yükseltilebilmesi için et, süt vb. hayvansal ürün üretimimizin artırılması ve bu ürünlerin ucuz bir şekilde piyasaya sunulması önem arz etmektedir.

Yeterli ve dengeli beslenme ile ilgili sorunlarımızın temelinde hayvancılığımız ile ilgili sorunlar yatmaktadır. Ülkemiz gerek yem sorunları ve gerekse izlenen yanlış politikalar nedeni ile ne yazık ki kırmızı eti en pahalı üreten ülkelerden biridir. FAO verilerine göre üretici bazında bir kilogram sığır etinin fiyatı İspanya'da 2.81, Almanya'da 3.76, Fransa'da 4.43, ABD'de 4.56 ülkemizde ise 7.52 dolardır [2]. Hayvan beslemede mevcut kaliteli kaba ve kesif yem açıkları yanında meraya dayalı hayvancılığın azalması et fiyatlarındaki pahalılığın temel nedenleri arasında sayılabilir. Ülkemizde hayvan beslenmede yem bitkilerinin yanı sıra doğal çayır-meralar, bitki artıkları ve anızlar ile saman gibi düşük kaliteli yemler yaygın bir şekilde kullanılmaktadır. Bu durum hayvancılıkta verimi azaltırken üretim maliyetlerinin yükselmesine neden olmaktadır. Nitekim 1995 yılında ülkemizdeki toplam sığır varlığı içerisinde yerli ırkların oranı \% 45, kültür ırklarının oranı \% 14 iken, bu oranlar 2017 yılında sırasıyla \% 11 ve \% 49 olarak gerçekleșmiştir [3]. Hayvan ırklarının bu dağılımına bakıldığında hayvancıllı̆ımızda genetik kapasitesi yüksek kültür ırkı hayvanların oranı önemli bir șekilde artarken daha düşük genetik kapasiteye sahip yerli ırk sığırların oranı düșmüștür. Ancak hayvancılı̆̆ımızda artan bu genetik kapasiteye paralel bir şekilde artış göstermeyen yem bitkileri ekim alanı kaliteli kaba ve kesif yeme olan ihtiyacın artmasına neden olmuştur. Ayrıca kesif yem üretimde kullanılan mısır, soya ve çeșitli küspeler gibi hammaddelerin ithalat yoluyla karşılanması ve döviz kurunda yaşanan dalgalanmalar hayvancılığımızda girdi maliyetlerinin yükselmesine ve karlılığın azalmasına neden olmuştur.

Ülke hayvancılığımızın karlı ve sürdürülebilir olabilmesi için hayvanların genetik potansiyellerinin ülkemizde üretilebilen yemlere uygun olması yanında kaliteli kaba yem üretebilen çayır mera alanlarının verimlerinin artırılması ve en önemlisi yem bitkileri ekim alanlarının artırılması büyük önem arz etmektedir. Kaba yemlerin kaliteli ve ucuz olması halinde, daha pahalı olan ve insan beslenmesinde de kullanılan yoğun ya da kesif yemlerin hayvan beslemede kullanımları da azalacaktır.

Yem bitkileri üretiminde en önemli girdilerinden biri tohumluk olup bu konuda temel ilke, verimli ve adaptasyon kabiliyeti yüksek tür ve çeşitlerin tohumluklarının üretilmesi ve pazarlanmasıdır. Ülkemiz bulunduğu coğrafi konum itibariyle birden fazla iklimi bünyesinde barındırmaktadır. Bu durum gerek yem bitkileri ve gerekse diğer ürünlerde farklı agro-ekolojik koşullara uygun tür ve çeşide duyulan ihtiyacı artırmaktadır. Adaptasyon yeteneği yüksek, kurağa ve soğuğa dayanıklı yem bitkisi tür ve çeşitlerine ait tohumlukların üretilmesi en başta kurak alanların ekim nöbetlerine yem bitkilerinin dahil edilmesine imkan sağlayarak nadas alanlarda kaliteli kaba yem üretimine olanak sağlayabilecektir. Diğer taraftan tarla tarımı içerisinde yem bitkilerinin ekim nöbetlerine girmesi sağlanarak yem bitkileri üretiminde önemli kazanımlar sağlanabileceği gibi 
Uluslararası Tohumculuk Federasyonu (ISF) verilerine göre dünya genelinde 23.1 milyar dolara ulaşan tohumluk ticaretinde önemli bir pay elde edilebilir [4].

Dünya tohum ticaretinde söz sahibi olan ülkelerin tohumluk üretimi ve yeni çeşitlerin geliştirilmesi konularında araştırma ve geliştirme çalışmalarına önem verdikleri bilinmektedir. Ayrıca bu ülkelerde özel sektörün tohumluk üretimi ve bitki sslahı konularında önemli bir paya sahip oldukları izlenebilmektedir. Özel sektörün tohumluk üretimindeki payının artırılması ancak bu alanın karlı ve sürdürülebilir olmasıyla mümkündür. Zira ülkemizde Tarım ve Orman Bakanlığı tarafından 2015 yılından itibaren uygulamaya konulan tohumluk üreticilerine yönelik yurt içi sertifikalı tohum üretim desteği ve üreticilere yönelik yurt içi sertifikalı tohumluk kullanım desteği sayesinde tohumluk üretiminde ve ticaretinde önemli gelişmeler kaydedilmiştir. Verilen bu desteklerle ortaya çıkan pazar neticesinde ülkemizde faaliyet gösteren özel sektöre ait yetkilendirilmiş tohumluk şirketi sayısında da artışlar kaydedilmiştir. Tohumluk üretimi ile diğer önemli bir konu da ilgili yasal düzenlemelerin günün ihtiyaçlarına göre düzenlemesidir. Ülkemizde 5553 sayılı Tohumculuk Kanunu 31 Ekim 2006 tarihinde çıkarılmıştır. Çıkarılan bu kanun ile bitkisel üretimde verim ve kaliteyi artırmak, kaliteli tohum üretimi sağlamak, tohumluk üretim ve ticaretinde düzenlemeler yapmak ve tohumculuk sektörünün yeniden yapılandırılması ve geliştirmesi amaçlanmıştır.

\section{Yem Bitkileri Üretimi ve Desteklemeleri}

Türkiye İstatistik Kurumu 2019 yılı verilerine göre ülkemizde toplam tarım alanı 37.71 milyon hektar olup bu alanın 15.39 milyon hektarını tarla tarımı alanları, 3.39 milyon hektarını nadas, 0.79 milyon hektarını sebze bahçeleri, 5 hektarını süs bitkileri, 3.5 milyon hektarını meyveler, içecek ve baharat bitkileri ve 14.62 milyon hektarını çayır ve mera arazileri oluşturmaktadır (Anonim, 2019a). Yem bitkileri ekim alanları ise 2019 yılı itibariyle 2.32 milyon hektar olup toplam tarla tarımı alanlarının \% 12.33'ünde yem bitkisi tarımı yapılmaktadır (Tablo 1 ).

Tablo 1. Yem bitkisi ekim alanlarının yıllara göre değiş̧imi (milyon ha)[5]

\begin{tabular}{cccccc}
\hline Yıllar & $\begin{array}{c}\text { Ekilen } \\
\text { Tarla Alanı }\end{array}$ & Nadas & $\begin{array}{c}\text { Toplam } \\
\text { Alan (A) }\end{array}$ & $\begin{array}{c}\text { Yem Bitkileri } \\
\text { Ekim Alanı (B) }\end{array}$ & $\begin{array}{c}\text { \% Yem Bitkisi } \\
\text { (B/A*100) }\end{array}$ \\
\hline 2001 & 17.917 & 4.914 & 22.831 & 0.358 & 1.57 \\
2005 & 18.005 & 4.876 & 22.881 & 0.942 & 4.12 \\
2010 & 16.333 & 4.249 & 20.582 & 1.461 & 7.10 \\
2015 & 15.723 & 4.114 & 19.837 & 1.863 & 9.39 \\
2016 & 15.575 & 3.998 & 19.573 & 1.867 & 9.54 \\
2017 & 15.532 & 3.697 & 19.229 & 1.993 & 10.37 \\
2018 & 15.421 & 3.513 & 18.834 & 1.987 & 10.55 \\
2019 & 15.387 & 3.387 & 18.774 & 2.315 & 12.33 \\
\hline
\end{tabular}

Yem bitkileri ekim alanlarında 2001 yılından günümüze kadar önemli gelişmeler kaydedilmiștir. Nitekim 2001 yılında 358 bin hektar olan yem bitkileri ekim alanı 2019 yılında 2.32 milyon hektara ulaşmıştır. Söz konusu yıllarda yem bitkilerinin toplam tarla tarımı alanlarındaki payı \% 1.57'den \% 12.33'e yükselmiştir (Tablo 1).

Tablo 2'de bazı yem bitkilerinin son 5 yıllık süre zarfındaki ekim alanları ile üretim değerleri gösterilmiştir. Son 5 yıl içerisinde yonca ekim alanlarında önemli bir değişiklik gerçekleşmezken korunga ve fiğ ekim alanlarında az da olsa azalmalar görülmüştür. Buna karşın silajlık mısır, İtalyan çimi, tritikale, yem bezelyesi ve sorgum ekim alanlarında artışlar kaydedilmiştir. Tablo 2'de yer verilmemiş olmakla birlikte buğday, arpa, çavdar 
ve yulaf gibi tahılların hasıl amacıyla ekildiğinde yem bitkisi olarak değerlendirilmiş ve destekleme kapsamına alınmış ancak bu uygulamaya 2019 yılında son verilmiştir.

Tablo 2. Bazı yem bitkilerinin ekim alanları (1000 ha) ve üretim miktarları (1000 ton) [5]

\begin{tabular}{|c|c|c|c|c|c|c|c|c|}
\hline \multirow[b]{2}{*}{ Yillar } & \multicolumn{2}{|c|}{ Yonca } & \multicolumn{2}{|c|}{ Korunga } & \multicolumn{2}{|c|}{ Fiğ } & \multicolumn{2}{|c|}{ Silajlık Mısır } \\
\hline & $\begin{array}{l}\text { Ekim } \\
\text { Alanı }\end{array}$ & $\begin{array}{l}\text { Kuru Ot } \\
\text { Üretimi }\end{array}$ & $\begin{array}{l}\text { Ekim } \\
\text { Alanı }\end{array}$ & $\begin{array}{l}\text { Kuru Ot } \\
\text { Üretimi }\end{array}$ & $\begin{array}{l}\text { Ekim } \\
\text { Alanı }\end{array}$ & $\begin{array}{l}\text { Kuru Ot } \\
\text { Üretimi }\end{array}$ & $\begin{array}{l}\text { Ekim } \\
\text { Alanı }\end{array}$ & $\begin{array}{c}\text { Silaj } \\
\text { Üretimi }\end{array}$ \\
\hline 2015 & 662.1 & 3487.5 & 191.4 & 414.0 & 436.5 & 1070.3 & 423.1 & 19684.6 \\
\hline 2016 & 650.1 & 3928.6 & 193.7 & 495.5 & 442.8 & 1135.5 & 425.7 & 20139.0 \\
\hline 2017 & 659.4 & 4390.3 & 196.2 & 500.4 & 445.6 & 1149.4 & 447.7 & 21613.1 \\
\hline 2018 & 635.1 & 4386.2 & 181.7 & 483.7 & 387.0 & 1068.5 & 472.6 & 23197.5 \\
\hline 2019 & 641.2 & 4487.3 & 175.3 & 445.5 & 391.5 & 1076.0 & 507.7 & 25499.9 \\
\hline \multirow[b]{2}{*}{ Yillar } & \multicolumn{2}{|c|}{ Yem Bezelyesi } & \multicolumn{2}{|c|}{ Sorgum } & \multicolumn{2}{|c|}{ Tiritikale } & \multicolumn{2}{|c|}{ İtalyan Çimi } \\
\hline & $\begin{array}{l}\text { Ekim } \\
\text { Alanı }\end{array}$ & $\begin{array}{l}\text { Kuru Ot } \\
\text { Üretimi }\end{array}$ & $\begin{array}{l}\text { Ekim } \\
\text { Alanı } \\
\end{array}$ & $\begin{array}{l}\text { Kuru Ot } \\
\text { Üretimi }\end{array}$ & $\begin{array}{l}\text { Ekim } \\
\text { Alanı }\end{array}$ & $\begin{array}{l}\text { Kuru Ot } \\
\text { Üretimi }\end{array}$ & $\begin{array}{l}\text { Ekim } \\
\text { Alanı }\end{array}$ & $\begin{array}{l}\text { Kuru Ot } \\
\text { Üretimi }\end{array}$ \\
\hline 2015 & 4.4 & 21.2 & 1.6 & 14.6 & 7.7 & 22.6 & 1.5 & 14.5 \\
\hline 2016 & 5.6 & 30.3 & 1.7 & 15.1 & 7.7 & 29.9 & 4.8 & 52.7 \\
\hline 2017 & 7.0 & 34.8 & 1.8 & 16.4 & 9.5 & 37.7 & 7.7 & 87.0 \\
\hline 2018 & 10.4 & 52.7 & 1.8 & 16.7 & 13.5 & 47.7 & 10.3 & 112.0 \\
\hline 2019 & 14.6 & 71.0 & 2.7 & 20.2 & 17.3 & 68.5 & 16.5 & 154.2 \\
\hline
\end{tabular}

Ülkemizde hayvancılığının geliștirilmesi ve hayvansal üretimin artırılması amacıyla Tarım ve Orman Bakanlığı tarafından 20.05.2000 tarihli Resmi Gazetede yayınlanan Hayvancılığın Desteklenmesi Hakkında Karar ile çok yıllık ve tek yıllık yem bitkileri üretimine ve yapay mera tesisine yönelik projeler belirli şartlar altında desteklenmeye başlamıștır. Bu karar ile ilgili uygulama esasları tebliği (Tebliğ No: 2006/9) 01.01.2006 tarihinde yürürlüğe girmiștir. Bu tebliğ ile yem bitkileri ekim alanlarının ve üretiminin arttırılması ile kaba ve kesif açıklarının tarla tarımı yapılan alanlardan karşılanması hedeflenmiștir [6]. Tablo 3'te bazı yem bitkilerine dekar bașına verilen destek miktarları yer almaktadır. Yıllar içerisinde yoncaya verilen destek miktarlarında değişiklikler olmasına rağmen yoncanın ekim alanlarında önemli bir değișiklik ortaya çıkmamıș, buna karșın yonca üretiminde düzenli artıșlar ortaya çıkmıștır. Bu durum, doğru yetiștirme teknikleri uygulanmasının yanı sıra kaliteli çeșitlerin üretimde kullanılmasıyla birim alan verimlerinin yükselmesinden kaynaklanıyor olabilir. Korungada yıllar itibariyle genel olarak destek miktarlarının artmasına rağmen ekim alanlarının azaldığı izlenmektedir. Oysa korunga gibi kurağa dayanıklı yem bitkileri nadas alanların daraltılmasında oldukça etkili olabilmektedir. Korunga ekim alanlarının artırılması için dekar bașına verilen desteklerin yanı sıra eğitim çalışmaları ile bitkinin tanıtılması yanında üreticiye ücretsiz tohum dağıtımları da etkili olabilir.

Tablo 3. Yıllar itibariyle ortalama yem bitkisi desteklemeleri (TL/dekar) [7]

\begin{tabular}{lccccccc}
\hline \multicolumn{1}{c}{ Yem Bitkileri } & 2000 & 2005 & 2010 & 2015 & 2017 & 2018 & 2019 \\
\hline Yonca & 17 & 95 & 125 & 50 & 60 & 90 & 90 \\
Korunga & 14 & 55 & 80 & 40 & 60 & 90 & 90 \\
Tek yıllık yem bitkileri & 7 & 37 & 30 & 35 & 40 & 60 & 60 \\
Silajlık tek yıllık yem bitkileri & 0 & 0 & 45 & 50 & 40 & 60 & 30
\end{tabular}




\begin{tabular}{lccccccc} 
Silajllk mısır & 10 & 60 & 50 & 35 & 90 & 100 & 100 \\
Yapay çayır mera & 0 & 0 & 75 & 100 & 150 & 150 & 150 \\
\hline
\end{tabular}

Tarım ve Orman Bakanlı̆̆ tarafından yem bitkileri üretimini artırmak ve tohumculuk sektörünün uluslararası alanda gelişmesini sağlamak amacıyla için yurt içi sertifikalı tohumluk üreten/ürettiren ve yurt içinde satışını gerçekleştiren yetkilendirilmiş tohumculuk kuruluşlarına 2008 yılından itibaren kilogram başına desteklemeler uygulamaya konmuștur. Bu kapsam da 2019 yılı itibariyle fiğ tohumluğu üretimine kilogram başına $1.5 \mathrm{TL}$, korunga tohumuna (meyve) 1.5, yem bezelyesine 1.5 ve yoncaya kilogram başına 4 TL destekleme ödemesi yapılmaktadır (Tablo 4). Ayrıca tohumluk üretiminde "orijinal" ve üstündeki kademelerdeki tohumluk üretimleri mevcut desteklere ilaveten \% 100 oranında desteklenmektedir. Bu uygulama ile ülkemizde yem bitkisi tohumluk üretiminde önemli gelişmeler kaydedilmiştir.

Tablo 4. Yurt içi sertifikalı tohum üretim destekleme miktarları (TL/kg) [7]

\begin{tabular}{lccccc}
\hline Yem Bitkisi & 2015 & 2016 & 2017 & 2018 & 2019 \\
\hline Fiğ & 0.5 & 0.75 & 0.75 & 1.5 & 1.5 \\
Korunga & 0.5 & 0.75 & 0.75 & 1.5 & 1.5 \\
Yem Bezelyesi & 0.5 & 0.75 & 0.75 & 1.5 & 1.5 \\
Yonca & 1.5 & 2 & 2 & 4 & 4 \\
\hline
\end{tabular}

Yem bitkileri tarımında birim alan verimlerinin artırılması ve tohumculuk sektörü için bir talebin oluşabilmesi amacıyla bakanlık tarafından yurt içi sertifikalı tohumluk kullanımı destekleri uygulamasına ait rakamlar Tablo 5'te görülebilmektedir. Buna göre yem bitkileri tarımında sertifikalı tohumluk kullanım desteklerinde yıllar itibariyle önemli iyileștirmeler yapılmıștır. 2019 yılı itibariyle sertifikalı tohumluk kullanım desteği yoncada $30 \mathrm{TL} /$ dekar iken fiğ, korunga ve yem bezelyesinde $20 \mathrm{TL} /$ dekar olarak belirlenmiştir.

Tablo 5. Bazı yem bitkilerinde sertifikalı tohumluk kullanım destekleri (TL/dekar) [7]

\begin{tabular}{lccccc}
\hline Yem Bitkisi & 2015 & 2016 & 2017 & 2018 & 2019 \\
\hline Fiğ & 7 & 10 & 10 & 20 & 20 \\
Korunga & 7 & 10 & 10 & 20 & 20 \\
Yem Bezelyesi & 7 & 10 & 10 & 20 & 20 \\
Yonca & 10 & 15 & 15 & 30 & 30
\end{tabular}

\section{Yem Bitkilerinde Tohumluk Üretimi}

Ülkemizde yem bitkileri tohumculuğunu diğer tarım ürünlerinde de olduğu gibi 1980'li yıllara kadar kamu ağırlıklı bir üretim modeli olușturmaktaydı. 1980'den itibaren tohumluk üretiminde özel sektörün önü kademeli olarak açllmış, 1998 yllında uluslararası tohumculuk federasyonuna (ISF) üye olunmuş ve 2004 yılında 5042 sayılı yeni bitki çeşitlerine ait ıslahçı haklarının korunması kanunu çıkarılmıştır. 2006 yılına 
gelindiğinde $\mathrm{AB}$ mevzuatı ile uyumlu 5553 sayılı tohumculuk kanununun çıkarılmasıyla özel sektörün tohumculuk üretiminde önü tamamen açılmıștır. 2007 yılında yeni bitki çeșitlerinin korunması ve bitki ıslahçıları hakları ile ilgili uluslararası yeni bitki çeșitlerini koruma birliği (UPOV) sözleșmesi imzalanmıș ve ülkemizde tohumculukla ilgili en önemli gelişmeler bu tarihten sonra ortaya çıkmıştır. Yem bitkileri özelinde ise yeni çeşit geliştirme çalışmalarını teşvik etmek ve kaliteli tohumlukların üretimini temin etmek amacıyla, tohumlukların üretilmesi ve pazarlanmasına ilişkin usul ve esasları belirleyen Yem Bitkileri ve Baklagil Tohumluğu Yönetmeliği” 05 Haziran 2015 tarihinde yürürlüğe girmiştir.

Tablo 6. Türkiye'de üretilen yem bitkisi tohumluğu miktarları (ton) [8]

\begin{tabular}{|c|c|c|c|c|c|c|c|c|c|c|c|c|c|}
\hline Türler & 006 & 2007 & 2008 & 2009 & 2010 & 2011 & 2012 & 2013 & 2014 & 2015 & 2016 & 2017 & 2018 \\
\hline Yonca & 508 & 678 & 517 & 864 & 349 & 473 & 670 & 610 & 560 & 634 & 794 & 887 & 3000 \\
\hline Korunga & 929 & 125 & 698 & 22 & 56 & 200 & 4 & 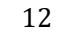 & 46 & . & 188 & 385 & 307 \\
\hline Fiğ & 2172 & 2206 & 2024 & 1057 & 858 & 876 & 876 & 385 & 686 & 974 & 1114 & 1139 & 1572 \\
\hline Sorgum sp. & 215 & 365 & 5 & 263 & 180 & 226 & 133 & 155 & 216 & 308 & 192 & 79 & 63 \\
\hline $\begin{array}{l}\text { Yem } \\
\text { Şalgamı }\end{array}$ & 2 & 5 & 0 & 1 & 0 & 14 & 12 & 55 & 92 & 18 & 53 & 6 & 11 \\
\hline $\begin{array}{l}\text { Yemlik } \\
\text { Pancar }\end{array}$ & 21 & 11 & 8 & 18 & 26 & 33 & 44 & 8 & 5 & 61 & 36 & 31 & 10 \\
\hline $\begin{array}{l}\text { Yem } \\
\text { Bezelyesi }\end{array}$ & & & & & 40 & 374 & 381 & 484 & 440 & 811 & 1585 & 2321 & 2121 \\
\hline Diğer & & & & & & & & 106 & 87 & 251 & 106 & 167 & 336 \\
\hline Toplam & 3847 & 3390 & 3252 & 2225 & 1509 & 2196 & 2118 & 1815 & 2132 & 3088 & 4068 & 5015 & 7420 \\
\hline
\end{tabular}

Tohumluk tüm tarım ürünlerde olduğu gibi yem bitkileri tarımında da en önemli girdilerin başında gelmektedir [9]. Kaliteli ve verimli bir üretim için yem bitkilerinde kullanılan tohumluğun genetik yapısının tarımı yapılan bölgenin ekolojik koşullarına iyi uyum sağlaması gerekmektedir [10]. Ülkemiz gibi birden fazla iklimi ve mikro ekolojik koşulları bünyesinde barındıran alanlarda bölgelere uygun yem bitkisi türlerine ait çeşitlerin geliştirilmesi verim ve kalite açısından önem arz etmektedir . Örnek vermek gerekirse, ülkemiz yoncanın önemli gen merkezlerinden biri olmasına rağmen bölgelerin sahip olduğu farklı sıcaklık ortalamaları nedeniyle güney ve kıyı bölgelerimizde yazlık veya dormansi derecesi yüksek yonca çeșitleri yetiştirilirken kışı sert geçen iç bölgelerimizde dormansi derecesi daha düșük olan çeșitlerin tarımı yapılmaktadır. $\mathrm{Bu}$ açıdan bölgelere uygun çeşit seçimi kıș zararı, seyrekleșme, hastalık ve zararlılara dayanıklılık, verim ve kalite gibi pek çok özelliği doğrudan etkilemektedir. Nitekim yapılan çalıșmalarda da bölgelere uygun çeşitlerin verim ve ürün kalitesini etkilediği bildirilmektedir [11, 12].

Tablo 6'da ülkemizin yem bitkileri tohumluk üretim değerleri görülmektedir. 2006 yılında 3847 ton olan yem bitkilerinde tohumluk üretimimiz yllar itibariyle dalgalanmalar göstermekle birlikte 2015 yılından itibaren kararlı artışlar göstermiş ve 2018 yılında 7420 tona yükselmiștir. Ülkemizde 2018 yılı itibariyle en fazla yonca, yem bezelyesi ve fiğ tohumluğu üretimleri gerçekleşmiştir. Tek yıllık baklagil yem bitkilerinden fiğ tohum üretim değerleri yıllar itibariyle azalış gösterirken yem bezelyesi tohumluğu üretim rakamlarında artışlar kaydedilmiştir. Bu durum üzerine son yıllarda kışa dayanıklı yeni yem bezelyesi çeşitlerinin geliştirilmesiyle fiğ tohumluğuna olan talebin azalmasının etkili olduğu düşünülebilir. Zira pek çok üretici tek yıllık baklagil yem bitkisi tarımında yem bezelyesini tercih etmekte ve her geçen gün çiftçiler tarafından fiğlerin yerine yem bezelyesi ekilmektedir [13]. 


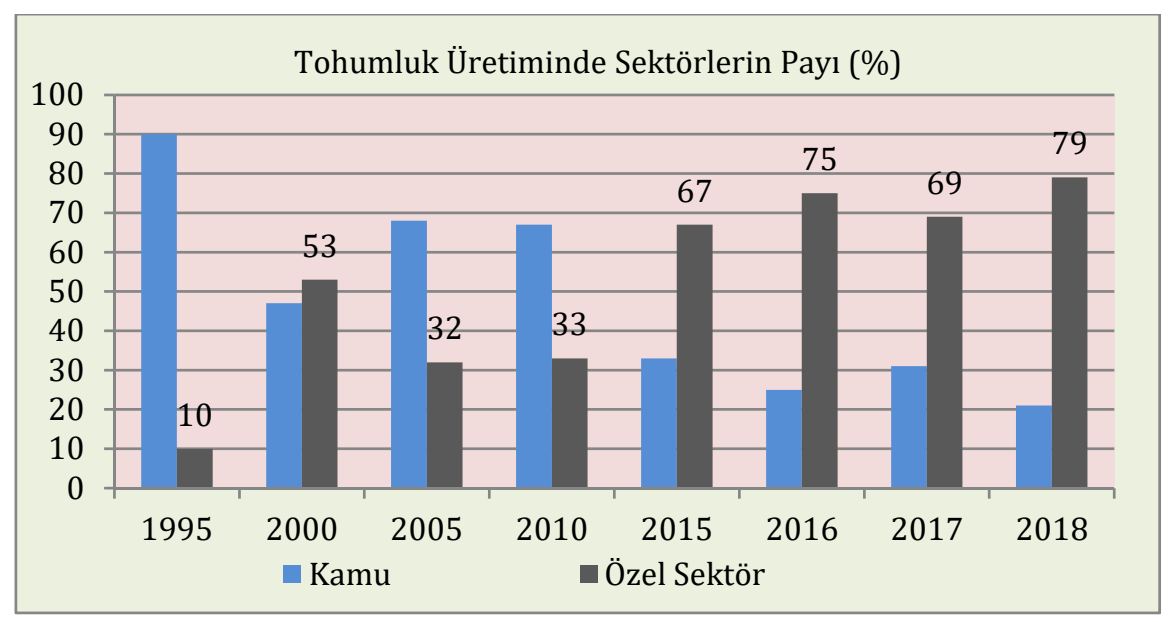

Şekil 1. Kamu ve özel sektörün tohumluk üretimindeki payı [8]

Yem bitkileri tohumluk üretiminde özel sektörün payı yıllar itibariyle artış göstermiştir. Özel sektörün payı 1995 yılında \% 10 iken bu oran 2018 yılında \% 79'a kadar yükselmiştir (Şekil 1). Bu artışlar üzerine 2015 yılında yürürlüğge giren Yem Bitkileri ve Baklagil Tohumluğu Yönetmeliği'nin yanı sıra yurt içi yem bitkileri tohumluk üretimi ve üreticiler için sertifikalı tohumluk kullanım desteklerinin uygulamaya girmesinin etkili olduğu düşünülmektedir. Nitekim yem bitkileri tohumluğu üretiminde özel sektörün payı 2015 yılından itibaren düzenli olarak artış göstermiştir.

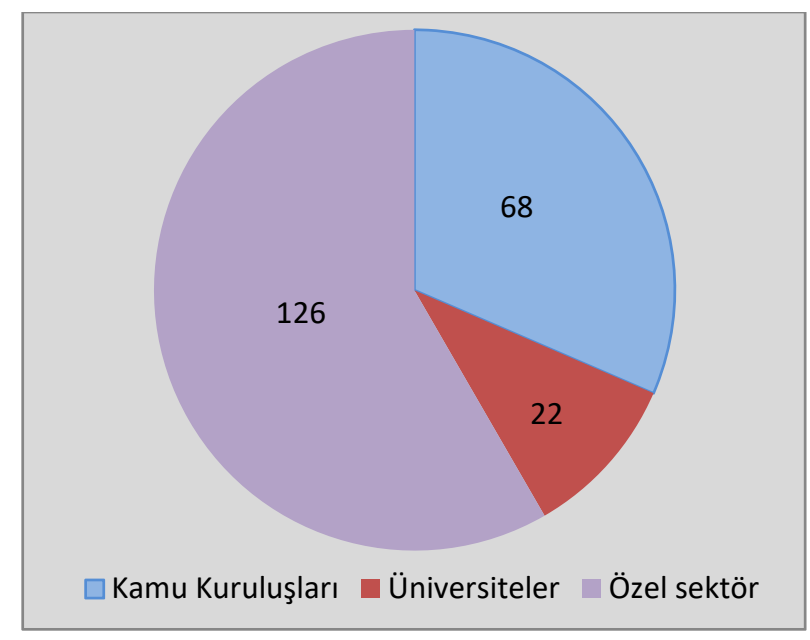

Şekil 2. Yem bitkilerinde kayıtlı çeşit sayıları [14]

Tarım ve Orman Bakanlığı, Tohumluk Tescil ve Sertifikasyon Merkez Müdürlüğü verilerine göre ülkemizde yem bitkilerinde tescilli 216 adet çeşit bulunmaktadır [14]. 
Yem bitkilerinde tescilli çeșitlerinin 68 adedi kamu kuruluşlarınca tescil ettirilmișken, 126 adedi özel sektör kuruluşları tarafından ve 22 adedi ülkemizdeki üniversiteler tarafından tescil ettirilmiștir (Șekil 2). Geliștirilen çeșit sayısı bakımından özel sektörün lider pozisyonda bulunması ülkemizin tohumculuk sektörünün gelişimi bakımından önemlidir. Ancak üniversitelerin çeșit geliștirme ve tescil ettirme noktasında kamu kurulușlarının gerisinde kalması üniversitelerde bu alandaki araștırma ve geliștirme çalıșmalarına yeterli kaynağın ayrılmadığının bir göstergesi olarak değerlendirilebilir. Şekil 3'te yem bitkisi türlerine göre tescilli çeșit sayılarına yer verilmiștir. Buna göre ülkemizde 56 adet ile en fazla tescilli çeşit yoncada bulunurken bunu 30 çeşit ile İtalyan

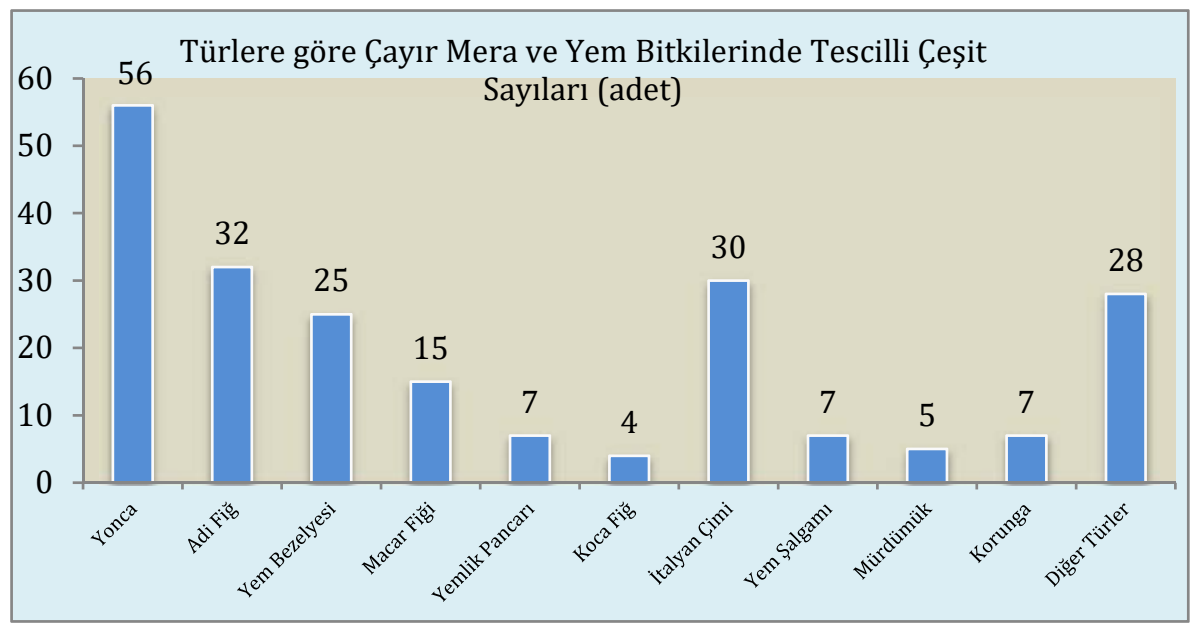

çimi ve 32 çeşit ile adi fiğ izlemiştir.

Şekil 3. Türlere göre çayır mera ve yem bitkilerinde kayıtlı çeşit sayıları [14]

\section{Yem Bitkileri Tohumculuğunun Dış Ticareti}

Türkiye Tohumcular Birliği verilerine dünya genelinde tohumluk sektörünün (tohum fidan ve süs bitkileri) üretim değeri 2019 yılı itibariyle 50 milyar USD dolaylarındadır. Bu değerin yaklaşı 12 milyar Dolarlık kısmını ABD oluştururken bu ülkeyi sırasıyla Çin (10 milyar USD), Fransa (2.8 milyar USD), Brezilya (2.1 milyar USD) ve Kanada (2 milyar USD) izlemektedir. Ülkemiz ise bu alanda 0.75 milyar USD'lik bir ile üretim değeri 11. sırada yer almaktadır [15]. Bazı araștırma kuruluşlarının tahminlerine göre 2023 yılında dünya tohumluk sektörünün ticaretteki payının 86 milyar USD seviyelerine ulaşacağı tahmin edilmektedir [16]. 2018 yılı itibariyle ülkemizin toplam tohumluk dış ticaret hacmi 331 milyon Dolar seviyelerindedir. Bu rakamın 152 milyon USD'sini ihracat oluştururken 179 milyon USD'sini tohum ithalatımız oluşturmaktadır. İhracatın ithalatı karşılama oranı ise \% 84.8'dir [15]. 
Tablo 7.Yem bitkisi tohumluk ihracat ve ithalatı [8]

\begin{tabular}{ccccc}
\hline Ylllar & \multicolumn{2}{c}{ İhracat } & Ithalat & \\
\cline { 2 - 5 } & $\begin{array}{c}\text { Miktar } \\
\text { (ton) }\end{array}$ & $\begin{array}{c}\text { Parasal Değer } \\
\text { (1000 USD) }\end{array}$ & $\begin{array}{c}\text { Miktar } \\
\text { (ton) }\end{array}$ & $\begin{array}{c}\text { Parasal } \\
\text { Değer } \\
(1000 \\
\text { USD) }\end{array}$ \\
\hline 2006 & 7 & 35 & 5532 & 11295 \\
2007 & 57 & 134 & 6868 & 12372 \\
2008 & 456 & 989 & 1420 & 4229 \\
2009 & 481 & 1476 & 1345 & 2810 \\
2010 & 1357 & 1691 & 1105 & 2826 \\
2011 & 281 & 1163 & 2147 & 6518 \\
2012 & 393 & 1191 & 2763 & 9880 \\
2013 & 483 & 1673 & 4121 & 15135 \\
2014 & 497 & 2093 & 3714 & 13424 \\
2015 & 589 & 1306 & 4134 & 8577 \\
2016 & 473 & 1069 & 6387 & 11111 \\
2017 & 740 & 992 & 9028 & 13474 \\
2018 & 979 & 1114 & 7809 & 16045 \\
\hline
\end{tabular}

Ülkemizde 1980 öncesinde yem bitkilerinde tohumluk ihracatı neredeyse yok denilecek kadar azdı. Ancak, zaman içerisinde tohumluk ihracatı yavaş da olsa bir gelişme göstermiștir. 2006 yılında 35.000 USD (7 ton) olan tohumluk ihracatı 2018 yılına gelindiğinde 1.1 milyon USD’ ye (979 ton) ulaşmıştır.

Ülkemizde hayvancılık sektörünün zaman içerisinde gelişmesi ve desteklemelerin de etkisiyle yem bitkisi ekiliş alanları son yıllarda sürekli artış göstermiştir. Artan ekim alanıyla birlikte tohumluk ihtiyacı da artmış ve bu ihtiyaç yerli üretimin yanı sıra ithalat yoluyla karşılanmıştır. Bu kapsamda 2006 yılında 11.2 milyon USD (5.532 ton) değerinde yem bitkisi tohumluğu ithal edilmiştir. Yem bitkilerinde tohumluk ithalatımız yıllar içerisinde dalgalanmalar göstermekle birlikte 2018 yılında 16 milyon USD'ye (7.809 ton) yükselmiştir (Tablo 7).

Yem bitkileri tohumculuğu dıș ticaretinin türlere ve ülkelere dağılımına ilișkin 2016 yılı verileri Tablo 8'de görülebilmektedir [17]. Buna göre yem bitkilerinde gereksinim duyulan tohumluk ihtiyacı 10 farklı ülkeden toplam 7.2 milyon USD değerinde ithalat yapılarak karşılanmıştır. Türler bazında en fazla tohumluk ithalatı çim ve çayır mera bitkilerinde 1820.7 ton olarak gerçekleşmiştir ve bu ithalat için 3 milyon USD ödenmiştir. Önemli miktarda çim ve çayır mera bitkileri tohumluğu aldığımız ülkeler Danimarka, ABD ve Hollanda'dır. Yem bitkileri tohumluğu ithalatı ikinci en önemli tür olarak yoncada olmuş ve bu kapsamda 2016 yllında 1451.2 ton yonca tohumu ithal edilmiștir. Yoncada en fazla tohum sirasiyla İtalya (850 ton), Almanya (240 ton), ve Kanada'dan (222 ton) gerçekleștirilmiştir. 
Tablo 8. Bazı yem bitkisi tohumluklarının 2016 yılı ithalat ve ihracat verileri [17]

\begin{tabular}{|c|c|c|c|c|c|c|}
\hline \multirow[b]{2}{*}{ Tohumluk } & \multicolumn{3}{|c|}{ İthalat } & \multicolumn{3}{|c|}{ İhracat } \\
\hline & Ülke & $\begin{array}{r}\text { Miktar } \\
\text { (ton) }\end{array}$ & $\begin{array}{r}\text { Parasal } \\
\text { Değer } \\
(1000 \\
\text { Dolar) } \\
\end{array}$ & Ülke & $\begin{array}{r}\text { Miktar } \\
\text { (ton) }\end{array}$ & $\begin{array}{r}\text { Parasal } \\
\text { Değer } \\
(1000 \\
\text { Dolar) } \\
\end{array}$ \\
\hline \multirow{5}{*}{ Yonca } & İtalya & 850.0 & 4081.1 & Libya & 17.0 & 75.4 \\
\hline & Almanya & 240.0 & 984.9 & Irak & 10.0 & 33.4 \\
\hline & Kanada & 222.0 & 997.2 & Gürcistan & 3.7 & 22.3 \\
\hline & Fransa & 70.2 & 344.8 & Özbekistan & 3.5 & 10.6 \\
\hline & İspanya & 69.0 & 342.9 & Kazakistan & 2.0 & 13.0 \\
\hline \multirow{5}{*}{$\begin{array}{l}\text { Çim ve Çayır } \\
\text { Otu } \\
\text { Tohumlukları }\end{array}$} & Danimarka & 1043.4 & 2078.2 & Özbekistan & 7.3 & 12.0 \\
\hline & $\mathrm{ABD}$ & 536.3 & 1177.3 & Kazakistan & 4.2 & 27.7 \\
\hline & Hollanda & 157.6 & 287.6 & Türkmenistan & 3.3 & 11.1 \\
\hline & İtalya & 60.4 & 131.2 & K.K.T.C. & 1.3 & 4.8 \\
\hline & Fransa & 23.0 & 48.9 & Etiyopya & 846.0 & 12.4 \\
\hline \multirow{2}{*}{$\begin{array}{l}\text { Hayvan } \\
\text { Pancarı }\end{array}$} & Hollanda & 9.6 & 22.7 & Özbekistan & 3.0 & 8.7 \\
\hline & Danimarka & 2.4 & 5.6 & Almanya & 1.0 & 7.1 \\
\hline \multirow{5}{*}{$\begin{array}{l}\text { Diğer Yem } \\
\text { Bitkileri }\end{array}$} & $\mathrm{ABD}$ & 467.0 & 1246.8 & Türkmenistan & 152.1 & 553.1 \\
\hline & İspanya & 399.9 & 1138.7 & Özbekistan & 23.5 & 65.2 \\
\hline & Danimarka & 6.0 & 23.4 & Irak & 15.5 & 66.8 \\
\hline & Macaristan & 5.0 & 25.0 & K.K.T.C. & 7.5 & 23.8 \\
\hline & Avusturya & 1.0 & 5.4 & Kongo & 2.5 & 9.9 \\
\hline Toplam & & 4162.8 & 12944.7 & & 1103.4 & 957.3 \\
\hline
\end{tabular}

2016 yılı verilerine göre ülkemizde 1103.4 ton yem bitkisi tohumluğu ihracatı gerçekleştirilmiştir. En fazla çim ve çayır mera bitkileri tohumlukları ihraç edilirken bunu diğer yem bitkisi türleri ve yonca izlemiștir. Yem bitkileri dış ticaretinde genel olarak ithalatın neredeyse tamamı batılı ülkelerden gerçekleştirilirken, ihracatımız Türki Cumhuriyetler, Orta Doğu ülkeleri ve bazı Afrika ülkelerine yapılmaktadır.

\section{Sonuçlar ve Öneriler}

Ülkemizde hayvancılık sektörü ve buna bağlı olarak yem bitkileri tarımında son yıllarda önemli gelişmeler kaydedilmiştir. Ekim alanları \% 1.57 seviyelerinden $\% 12.33$ dolaylarına ulaşmıştır. Ekim alanı artan türleri genel olarak sulanabilir alanlarda tarımı yapılan yem bitkisi türlerinin oluşturduğu izlenmektedir. Bu durum memnuniyet verici olmasına rağmen nadas alanların daraltılmasında etkili olan, kurağa dayanıklı yem bitkilerinin ekim alanlarının artırılması, yem bitkileri konusundaki büyümenin sürdürülebilir olması açısından önemlidir.

Tohumculuk alanında son yıllarda önemli kazanımların elde edildiği bir gerçektir. Ancak ülkemiz tohumculuk konusunda halen arzu edilen noktada değildir. Toplam tohumluk dış ticaretimizde ihracatın ithalatı karşılama oranı \% 84.8 seviyelerinde iken bu oran yem bitkileri tohumculuğunda 2016 yılı için \% 6.9 seviyelerindedir. Yem bitkileri içerisinde en fazla ithalat çim, çayır mera tohumları ile yonca tohumlarında gerçekleşmektedir. $\mathrm{Bu}$ sebeple yonca, çim ve çayır mera bitkileri tohumluk üretimi ve bu alandaki ar-ge çalışmaları özel olarak desteklenmelidir. Ülkemiz iklim özellikleri itibariyle oldukça çeşitlilik göstermektedir. Bu nedenle farklı bölgeler için çok sayıda yem bitkisi çeşidine 
ihtiyaç duyulmaktadır. Tescilli yem bitkisi çeşit sayısının artırılması önem arz etmektedir. Tarımsal yapı itibariyle küçük ölçekli işletmelerden olușan ülkemiz tarımında eğitim ve yayım çalışmaları ile üreticiler bilinçlendirilmeli, birlik ve kooperatifleşme faaliyetleri teșvik edilmelidir.

Tohumluk üretiminde ve ticaretinde özel sektörün geliştirilmesine özen gösterilmelidir. Gelişmiş ülkelerde üretimin çok büyük bir kısmını özel şirketler gerçekleștirmektedir. Özel sektörün gelişebilmesi için son yıllarda uygulamaya konan yurt içi sertifikalı tohumluk kullanım desteği bu alanda bir pazar oluşmasını sağlamış ve akabinde tohumculuk şirket sayıları ve yatırımları artmıştır. Ayrıca yurt içi sertifikalı tohumluk üretim desteği de sektörün gelişmesine büyük katkılar sağlamıştır. Bu teşviklerin artırılarak devam ettirilmesi tohumculuk sektörünün gelişmesine katkılar sağlayacaktır. Yerli üretimin teşvik edilmesi için ithalat vergileri, ihracatta vergi indirimleri konularında yapılacak yasal düzenlemelerle yabancı menşeili şirketlerin ülke içindeki yatırımlarının artırılması sağlanabilir. Kayıt dıșı üretimin kontrol altına alınarak haksız rekabetin önüne geçilmelidir. Tohumculuk şirketlerinin kooperatifler veya birlikler bünyesinde örgütlenmeleri özendirilmelidir. Ar-ge konusunda kamu-üniversite-özel sektör bağı güçlendirilmeli, alt yapı sorunu yaşayan küçük ölçekli işletmelerin laboratuvar, nitelikli teknik eleman vb. ihtiyaçlarının karşılanmasında gerekli kolaylıklar sağlanmalıdır. Çeşit tescili ve sertifikasyon konularında özel sektör sürece dahil edilerek kamunun tesiri azaltılmalıdır.

\section{Kaynaklar}

1. Cevheri AC ve Polat T. Şanlıurfa'da yem bitkileri tarımının dünü, bugünü ve yarını. H.Ü.Z.F. Dergisi. 2009;13(1): 63-67.

2. Anonim. United Nations Food and Agricultural Organisation (FAO), Annual Producer Prices; 2014. Son erișim tarihi: 10 Mayıs 2020. http://www.fao.org/faostat/en/\#data/PP 3. Anonim. Türkiye İstatistik Kurumu, Hayvancllık İstatistikleri; 2017. Son erișim tarihi: 16 Nisan 2020. http://www.tuik.gov.tr/PreTablo.do?alt id=1002

4. Anonim. International Seed Federation, Seed Statistics; 2017. Son erişim tarihi: 03 Mart 2020. https://www.worldseed.org/resources/seed-statistics/

5. Anonim. Türkiye İstatistik Kurumu, Bitkisel Üretim İstatistikleri; 2019. Son erişim tarihi: 16 Mayıs 2020. http://www.tuik.gov.tr/PreTablo.do?alt id=1001

6. Ünal S. Yem bitkilerinde tohumluk üretimi. Tarla Bitkileri Merkez Araştırma Ens., Dergisi, 2004:13(1-2) https://dergipark.org.tr/tr/pub/tarbitderg/issue/11508/137058 7. Anonim. T.C. Tarım ve Orman Bakanlığı, Bitkisel Üretim Genel Müdürlüğü, Tarımsal Destekler; 2019. Son erişim tarihi: 20 Nisan 2020. https://www.tarimorman.gov.tr/BUGEM/Menu/31/2019-Uretim-Sezonu-BitkiselUretim-Destekleme-Birim-Fiyatlari

8. Anonim T.C. Tarım ve Orman Bakanlığı, Bitkisel Üretim Genel Müdürlüğü, Tohumculuk İstatistikleri; 2018. Son erişim tarihi: 25 Mart 2020.

https://www.tarimorman.gov.tr/Konular/Bitkisel-Uretim/Tohumculuk/TohumculukIstatistikleri

9. Türk M, Gösterit A, Alagöz M, Buluş İY. Korunga tohum üretiminde bal arıların rolü. 6 . Uluslararası Muğla Arıcılık ve Çam Balı Kongresi; 15-19 Ekim 2018; Muğla, Türkiye.

10. Açılkgöz E. Yem Bitkileri, Yem Bitkilerinde Tohum Üretimi, Uludağ Üniversitesi, Zir. Fak., Tarla Bit. Böl. s.333-362, Bursa, 2001.

11. Alagöz M ve Türk M. Determination of yield and some properties of different silage corn varieties in Isparta ecological conditions. Turkish Journal of Agriculture - Food Science and Technology 2019; 7: 193-197. 
12. Türk M ve Alagöz $M$. The effect of nitrogen fertilizer on the yield and quality in the sweet maize. Scientific Papers. Series A. Agronomy 2018; 56: 408-411.

13. Özaslan Parlak A ve Göçmen N. Yem bezelyesi ile arpa, yulaf ve tritikale karışım oranlarının belirlenmesi. ÇOMÜ Zir. Fak. Derg., 2017:5(1): 119-124.

14. Anonim. Tarım ve Orman Bakanlı̆̆ı, Tohumluk Tescil ve Sertifikasyon Merkez Müdürlüğü. Milli Çeșit Listesi; 2020. Son erișim tarihi: 01 Haziran 2020. https://www.tarimorman.gov.tr/BUGEM/TTSM/Sayfalar/Detay.aspx?SayfaId=85

15. Anonim. Türkiye Tohumcular Birliği, 2019 Yılı Tohumculuk Sektör Raporu; 2019. Son erișim tarihi: 11 Haziran 2020.

https://turktob.org.tr/upload/SEKTOR RAPORU 2019 TURKTOB WEB ICIN.pdf

16. Anonim. Statista, Forecast Value Seed Market Worldwide from 2017 to 2023; 2020. Son erişim tarihi: 16 Haziran 2020. https://www.statista.com/statistics/262286/globalseeds-market-value/

17. Anonim. Tohum Sanayicileri ve Üreticileri Alt Birliği, Tohum Dış Ticaret Verileri; 2016. Son erişim tarihi: 30 Nisan 2020. http://www.tsuab.org.tr/Page/7257/6 